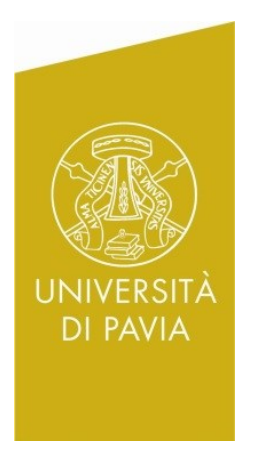

Department of Economics and Management

DEM Working Paper Series

\title{
The Smoking Epidemic across Generations, Gender and Educational Groups: A Matter of Diffusion of Innovations
}

\author{
Cinzia Di Novi \\ (Università degli Studi di Pavia) \\ Anna Marenzi \\ (Ca’ Foscari Università di Venezia) \\ \# 153 (02-18) \\ Via San Felice, 5 \\ I-27100 Pavia \\ economiaweb.unipv.it
}

February 2018 


\title{
The Smoking Epidemic across Generations, Gender and Educational Groups: A Matter of Diffusion of Innovations
}

\author{
Cinzia Di Novi*, Anna Marenzi ${ }^{+}$
}

\begin{abstract}
This study examines whether the temporal variations in smoking habits across generations and gender and among groups with differing levels of education fit the pattern proposed by the theory of the diffusion of innovations (TDI) (Rogers, 2003). We focus on the Italian case and employ a pseudo-panel derived from repeated crosssections of the annual household survey, "Aspects of Daily Life," that is part of the Multipurpose Survey carried out by the Italian National Statistical Office (ISTAT) for the period 1997 to 2012. The results confirm Rogers' TDI and show that smoking prevalence has declined over time and across age cohorts: younger men of all educational levels and women with higher education are less likely to smoke than are those in other cohorts. On the other side, less-educated women, who entered the smoking-diffusion process later that others are more likely to smoke. Hence, socioeconomic differences in smoking continue to persist, especially for women. According to Rogers' TDI, smoking prevalence is expected to decline further, particularly among little-educated women.
\end{abstract}

Keywords

Smoking habit, theory of diffusion, generations JEL Codes

$\mathrm{J} 1, \mathrm{I} 1$

\footnotetext{
${ }^{*}$ Corresponding author: Cinzia Di Novi, Department of Economics and Management, University of Pavia, via San Felice, 5, Pavia, Italy; Health, Econometrics and Data Group, University of York; LCSR, National Research University Higher School of Economics, Russian Federation Email: cinzia.dinovi@unipv.it.

${ }^{+}$Department of Economics, Ca' Foscari University of Venice, San Giobbe, Cannaregio 873, 30121 Venice, Italy. Email: anna.marenzi@unive.it.
} 


\section{Introduction}

The popularity of tobacco smoking has changed dramatically in western countries. At the beginning of the twentieth century, cheap mass production and the use of cigarette advertising allowed tobacco companies to expand their markets. Older cohorts, who entered adolescence in a period characterized by a growing access to cigarettes and a lack of information about the health-damaging consequences of smoking (which were confined at that time to the medical literature debate), were easily attracted to smoking. Among older cohorts, smoking was initially highest among people in higher socioeconomic positions, but at some point, the positive socioeconomic gradient reversed and the social distribution of smoking reversed. Among younger cohorts, the association between smoking and low socioeconomic status has increasingly strengthened, and smoking has become disproportionately common among the economically disadvantaged. As a result, it has emerged as one of the most important contributing factors to inequalities in health (Di Novi et al., 2017).

A growing literature (Lopez et al., 1994; Pampel, 2005; Mackenbach, 2006; Veday, 2014) suggests a typical trajectory for smoking uptake that fits the pattern proposed by the theory of diffusion of innovations (Rogers, 2003). According to this literature, the rise and fall of smoking is analogous to an epidemic, where smoking spreads from relatively small parts of a population to other parts and then declines. The trajectory follows four stages: In the first stage, smoking was undertaken mainly by men in higher socio-economic groups (early adopters), who were more open to innovations and endowed with sufficient resources to adopt them. In the second stage, smoking became more common and more equally distributed across a large part of the population (early majority); the socioeconomic gradient diminished because of increased prevalence among less affluent socioeconomic groups. In the third stage, the prevalence of smoking has peaked and started to decline, especially among those who are better off, while remaining relatively constant among the rest of the population (later majority). In the last stage, as an "older innovation," smoking will become a habit of lower socioeconomic groups (laggards) who adopted it later in the diffusion process. In the smoking epidemic, women lag men by one or two decades. The later 
spread among women may be one of the reasons for the continuing gender heterogeneity in smoking prevalence.

According to this four-stage trajectory, one source of heterogeneity in smoking prevalence is individuals' socioeconomic position, where education is, perhaps, the most basic component. A lower education level, which may be an effect of a lifetime of socioeconomic limitations, is often associated with a higher risk of smoking (Assaf et al., 2017). Education also plays a pivotal role in the diffusion of the smoking habit, as the more highly educated were the first to adopt smoking early in the epidemic and the first to reject it later (Pampel, 2005; Veday, 2014).

This study addresses the diffusion of the smoking habit in Italy. Specifically, our contribution seeks to determine whether the temporal variations in smoking habits among groups with differing levels of education is consistent with the predictions of the tobacco epidemic model (Rogers, 2003), taking into account the separate effects of gender, age, and birth cohort. We employ a pseudo-panel derived from repeated cross-sections of the annual household survey "Aspects of Daily Life," which is part of the Multipurpose Survey carried out by the Italian National Statistical Office (ISTAT) for the period 1997 to 2012. Smoking data from this survey has already been examined extensively, but linking the cross-sections gives additional richness to the data and offers an opportunity to investigate the changes in smoking prevalence over time, age, and cohorts. Moreover, a pseudo-panel approach helps to clarify trends in smoking better than is possible from the cross-sectional data alone.

To the best of our knowledge, this study is the first to provide empirical evidence for the diffusion theory of smoking across generations for Italy using representative data for the whole Italian population. The Italian context is similar in many ways to that of other countries in Southern Europe. However, because of Italy's early focus on anti-smoking policies, which may have directly affected tobacco consumption and because of the historical gap in the economic performance between the more developed North and the less developed South, the country provides a useful case study. Southern regions are the opposite side of the northern coin with regard to education attainment and social and cultural factors that may have influenced the spread of smoking (ISTAT, 2016). This study also seeks to determine whether the contraposition between northern and southern Italy has produced differences in the diffusion of smoking habits between these two areas. 
Our results confirm Rogers' theory of the diffusion of innovations (TDI) and show that smoking prevalence has declined over time and across birth cohorts: men of younger cohorts of all educational levels and women with higher levels of education are less likely to smoke than are other cohorts. On the other hand, less-educated women, who entered the smoking diffusion process later, still show high prevalence rates compared to the older generation, especially in the South, where smoking started later.

Our study sheds light on how changes across generations and social contexts may have influenced the smoking habit's diffusion. By explaining generational changes in smoking habits and testing the diffusion theory, this study may help to predict future trends and differences in smoking behavior.

The remainder of the paper is organized as follows. Section 2 describes the smoking diffusion across birth cohorts and the government policy against smoking in Italy. Section 3 describes the data and the empirical model, while the results are presented and discussed in Section 4. Concluding remarks are reported in Section 5. The sensitivity analysis is available in the Appendix.

\section{The Diffusion of Smoking across Generations in Italy}

The smoking epidemic in Italy started later than it did in other European countries, in part because of the relative poverty of the average Italian at the beginning of the twentieth. On the other hand, Italy introduced anti-smoking policies earlier (in terms of the diffusion of smoking in the country), as they did so in the 1970s, which is in line with most European countries. At that time, the increased awareness of the damage caused by tobacco smoking led the Italian government to prohibit tobacco advertising and then to introduce bans on smoking in public places, which contributed to the declining social acceptance of smoking. However, the view of smoking as a negative health behavior might have differed substantially between younger and older generations because of their differing beliefs about smoking. Here, we review the diffusion of smoking in Italy across generations, focusing in particular on the "Silent Generation" (born 1926-1945), the "Baby Boomers" (born 1946-1965), and the "X Generation" (born 1966-1980). 
According to ISTAT (2016) ${ }^{1}$, the Silent Generation, born between 1926 and 1945, are the protagonists of the post-World War II period. They entered adolescence and early adulthood between 1940 and 1960, in a period characterized by the absence of anti-smoking policies and by the growth in cigarette consumption as an index of economic well-being and modernism. Smoking was almost exclusively a male habit; the growth of cigarette smoking among women occurred much later because of the strong social taboos and religious attitudes that characterized this generation (Ipsen, 2016). Women were also less affluent than men and so less like to be able to afford cigarettes.

Cigarette smoking grew rapidly, reaching its peak in the Baby Boomers' era. ISTAT identifies two subgroups in the Baby Boom generation: the Baby Boomer 1, consisting of those born between 1946 and 1955, who were the protagonists of the social revolutions and cultural changes of the 1970s, and the Baby Boomer 2, consisting of those born between 1956 and 1965, who grew up in a period of improved economic wellbeing, rapid technological innovation, many job opportunities, and general stability. The Baby Boomer 1 generation grew up in a period in which smoking was a mass behavior: According to La Vecchia et al. (1986), upwards of 60 percent of men aged 20-50 smoked in the 1960s. In the same period, smoking prevalence was low for women (around 11\%), but the negative stereotype of smoking for women was abandoned later by women in the Baby Boomer 2 generation.

Baby Boomer 2 entered adolescence and early adulthood in a social context characterized by the first policies against tobacco smoking. In 1972, Italy banned all forms of tobacco advertising, sponsorship, and broadcast. In 1975, the Italian government introduced the first legislation regulating smoking in public places, which banned smoking in all public transport. During the 1980s, the decline of smoking was manifest in males, but smoking increased among females. Women's tobacco use was almost exclusively in the form of cigarettes and was interpreted as symbol of freedom and emancipation (Hunt et al., 2004; Tinkler, 2006). Again, women in higher socioeconomic classes "emancipated" faster and earlier than did those in lower socioeconomic classes.

\footnotetext{
${ }^{1}$ ISTAT defines a generation as an identifiable group that shares birth years and significant historical events. Compared to other papers, this paper may vary in the birth year that begins or ends a generation based on the source to which the researchers refer.
} 
Finally, Italy entered the antismoking era in the 1990s when, the children of the Baby Boomers-that is, the $\mathrm{X}$ Generation-entered adolescence. The $\mathrm{X}$ Generation, which consists of those born between 1966 and 1980, have grown up between the old and the new millennium in a period characterized by tobacco-control measures like anti-tobacco campaigns, public health programs, stringent smoking bans, and increased information about the health problems caused by cigarette smoking.

Beginning in 1990, in Italy, warnings that smoking is dangerous to health appeared for the first time on cigarette packs and all other tobacco products. In the same period the NHS and non-governmental organizations (in particular, the Italian Anti-Cancer Association, LILT) promoted the first Smoking Cessation Services (SCS), although these services were concentrated in the northern regions, as remains the case today (Table A.1, in the Appendix).

In January 2003, Italy became the first large European Union country to approve a strict and comprehensive smoking ban, which came into effect in January 2005. The Italian government banned smoking in all indoor public places, including offices, cafes, restaurants (except for a few with separate and regulated smoking areas), airports, and railway stations. In order to deter young people from taking up the smoking habit, in January 2016, the Italian government banned shops from selling "kiddy packs," cigarettes in packs of ten. Tobacconists caught selling cigarettes to minors risk fines of up to 3,000 euros or losing their licenses. The new legislation made it illegal to smoke in cars that carried children or pregnant women, prohibited smoking outdoors near schools and hospitals, and required more stringent labeling and packaging of cigarettes.

\section{Empirical Analysis}

\subsection{Data and Estimation Strategy}

To test the TDI in smoking habits, we adopt an APC approach, which provides a powerful method for testing theories that involve age, period, and cohort effects (O’Brien, 2000). We employ a pseudo-panel derived from repeated cross-sections of the 
annual household survey, "Aspects of Daily Life," part of the Multipurpose Survey system carried out by the ISTAT. The analysis uses fifteen years of repeated crosssections from 1997 to 2012. (The 2004 survey was not fielded.) ${ }^{2}$ To construct the pseudo-panel, we divide each year's observations into cohorts (individuals who share some common characteristics) and use these cohorts to estimate a fixed-effects model from repeated cross-sections (Deaton, 1985). The main assumption behind the construction of a cohort is that respondents who share a set of characteristics that do not change (e.g., birth year, gender) or that remain broadly constant over time (e.g., region of residence) have similar smoking behavior and can be treated as a single observation (Verbeek, 2008).

In choosing the width of the cohort, we aggregate birth cohorts based on the ISTAT definition of generations (Section 2) to assess the differences in smoking across generations ("generation effects"). These birth cohorts link individuals who have experienced the same historical events in terms of unveiling the harmful consequences of smoking to the public. We follow the experiences of four birth cohorts: those born 1926-45 (the Silent Generation), 1946-55 (the Baby Boomer 1 Generation), 1956-65 (the Baby Boomer 2 Generation), and 1966-80 (the X Generation). Then we consider the trade-off between the need to have as much informative data as possible and the need to have a sufficiently large number of observations per cell to reduce the potential of error in the estimate of the cohorts' means. A large number of observations within each cell helps to ensure that the necessary asymptotic theory is applicable to the pseudo-panel approach. ${ }^{3}$

Our choice of cohorts includes two pseudo-panels, one for each gender for each of four birth cohorts, two educational levels (those who left school at the compulsory age and those who undertook additional voluntary; see also Banks et al., 1998) in nineteen regions, over fifteen years. 4 The resulting average number of individuals per cell is 122

\footnotetext{
${ }^{2}$ An assessment of the surveys was made to check their comparability and consistency. Given the repeated nature of the Multipurpose Survey, its various years have similar survey design, scope, coverage, sampling unit, reporting method, mode, and weighting method. Questionnaire wordings for most variables of interest are also similar across the surveys. Where there are some differences with respect to some variables, efforts were made to align their definitions and/or categories as closely as possible across the surveys prior to pooling the data.

3 The problem of the number of individuals in a cell can be ignored and cohort data can be treated as genuine panel data if the number of individuals in each cell is above 100 (Verbeek, 2008).

4 The cut-off we use for the respondents' educational level may seem crude at first and to involve significant loss of information. However, this construction allows us to assume that education is a timeinvariant characteristic since all of the participants included in the sample were old enough to have
} 
for males and 133 for females (Table A2, in the Appendix). Cells with thirty of fewer individuals were excluded from the analysis to ensure robust estimates of the subgroups' mean statistics.

Finally, we average all of the relevant variables over the year-among individuals of the same gender, within birth cohorts, educational levels and regionsto get a time series for each cohort (Deaton, 1985). Descriptive statistics are shown in Tables $1 \mathrm{a}$ and $1 \mathrm{~b}$.

Although microeconomic heterogeneity is clearly reduced in pseudo-panels, this approach presents two primary advantages over those of a genuine panel: First, the approach does not suffer from the problem of non-random attrition that occurs with conventional panel data, because a new sample is drawn each survey year. Second, the wide availability of cross-sectional data allows us to build a pseudo-panel that covers substantially longer periods than those that can be covered by real panels.

\subsection{APC models and the "identification problem"}

From a methodological point of view, age-period-cohort models suffer from an identifiability problem because of the exact relationship between the variables: year of birth plus age equal calendar year (cohort + age = period). Hence, unrestricted age, cohort, and period effects cannot all be separately identified (van Kippersluis et al., 2009). The literature makes several attempts to find a solution to the identification problem. One of the most common solutions is to constrain certain parameters in a model to be equal. (For details, see Bell and Jones, 2013.) Each age group and birth cohort group is included in a regression model as a dummy variable, but two age groups and cohort groups are combined to be a single group. (See, for instance, Propper et al., 2001.) This approach solves the problem of perfect collinearity; however, as Glenn (2005) points out, "When this is done, the linear dependence is broken in the statistical model only and not in the real world, and thus, the obtained estimates of effects are not meaningful” (p. 12).

been able to complete at least the compulsory education. Moreover, the dichotomization of education allows us to test the TDI among differing educational groups with larger cell sizes and more robust results. 
We address the identification problem by employing a solution from Deaton (1985), where temporal change is decomposed into birth-cohort dummies and a continuous age profile, while period effects are regarded as exogenous shocks that sum to zero in the long run. Based on Bell and Jones (2013) and Veday (2014), we assume that changes in smoking habits over time is the result of birth cohorts' differing attitudes toward smoking, rather than period effects, and allocate temporal trends to variations in age or cohort. (See also Veday, 2014.) We estimate a separate regression equation for each educational level (compulsory vs voluntary education.) Hence, our model for the estimations, for each gender and education group, is given as follows:

\section{Smoking Prevalence st $=a$ Age $_{c t}+\beta$ Generations (Silent Generation as reference category) $+\gamma$}

Regions (Lombardy as reference category) $+\varepsilon_{c t}$

Our dependent variable is the prevalence of smoking. The smoking questions were comparable across all surveys, and responses were classified by a dichotomous variable indicating "not daily smoking" (also termed "non-smoker," meaning no current tobacco use) versus "daily smoking” (including all current daily tobacco use). Then, using cohort data, the dependent variable is transformed into the proportion of individuals who are current smokers in the cohort c, with level of education e, in region $r$ and in period t. Age is included as continuous variable, and birth cohorts, and regions are included as dummy variables.

To test the robustness of our results, we also re-run the model by assuming that period effects on smoking prevalence could derive from a business cycle effect that operates through economic conditions (Ruhm, 2005; Chang et al., 2016; Kaiser et al., 2017). The results of our sensitivity analysis are shown in the Appendix (see Tables A.4a and A.4b).

\section{Results}

Figure 1, which plots the age profile of the proportion of individuals who are current smokers, shows that smoking initially increases with age, plateaus around age forty-five, and falls thereafter (observable only for the older cohorts). Figure 1 highlights two traits of smoking behavior for males and females: First, males, independent of their birth cohort, are more likely to smoke than females are. Second, a 
cohort effect is apparent, as the proportion of male smokers in the younger cohorts is lower than it is among older cohorts, and for females the Baby Boomer 2 Generation has the highest smoking prevalence.

Figures $2 \mathrm{a}$ and $2 \mathrm{~b}$ show the smoking age profile according to the respondents' level of education, which is one of the crucial measures of socioeconomic status in explaining the TDI. (See, for instance, Pampel, 2005.) In general, a higher level of education is associated with lower smoking prevalence, and the decline in smoking with age tends to be steeper for both males and females who have only compulsory education. Figures $2 \mathrm{a}$ and $2 \mathrm{~b}$ show that males who belong to the Baby Boomer 1 Generation and females who belong to the Baby Boomer 2 Generation have the highest smoking prevalence rates, and the prevalence is higher when the level of education is lower.

Tables 2 and 3 show the results from the gender-specific regression models according to education. ${ }^{5}$ The effect of age on smoking prevalence confirms the pattern illustrated in Figure 1: age has a negative influence on the probability that an individual is a smoker, and the age effect is stronger for men than it is for women. As Table 2 shows, the decline in smoking prevalence is almost twice as large for men with voluntary education as it is for those with only compulsory education. For women (Table 3), the age effect on the decline in the probability of smoking is similar across education groups.

According to the World Health Organization, most people in industrialized countries who are addicted to nicotine started smoking during adolescence, and between a third and half of adolescents who experiment with smoking go on to become regular smokers (Samet and Yoon, 2010). As explained in Section 2, males in the Silent Generation entered adolescence, the most vulnerable period for starting tobacco use, during the first stage of the smoking epidemic, when smoking was diffused mainly among men of higher socioeconomic status. Males in the Baby Boomer 1 Generation entered adolescence during the second stage of the smoking epidemic (in the 1960s and 1970s), when smoking diffused to include lower socioeconomic groups,

\footnotetext{
${ }^{5}$ All models were estimated using least squares, weighted for number of observations per cell, as the cohorts differ in size. The adjusted R-squared is higher for the regression model that concerns the lowest education group. This results support the idea that age, birth cohorts, regional dummies are more predictive in the model that refers to compulsory education compare to the one which refers to voluntary education.
} 
and the prevalence increased rapidly. Table 2 shows that males in the Baby Boomer 1 Generation have the highest smoking prevalence rate relative to the other generations and that the difference in smoking prevalence between males with additional voluntary education and those with only compulsory education is small.

By contrast, males in the Baby Boomer 2 Generation entered adolescence in the third stage of the smoking epidemic, a period characterized by increasing scientific evidence of the health threat of smoking. In the 1970s and 1980s, the Italian government introduced the first policies against tobacco smoking, and thanks to these policies, knowledge about the harmful effect of tobacco consumption reached at least the most educated public. Tobacco use was recognized as an addiction and a cause of cancer, and concerns about the ill effects of breathing secondhand smoke began to spread. As shown in Table 2, those in the Baby Boomer 2 Generation who have a higher level of education are less likely to smoke than are those in the older cohorts, while smoking among less-educated men is not statistically different from that of the older, less-educated cohorts. As shown in Table 3, smoking rates peaked among females at the same stage, as women in the Baby Boomer 2 Generation have the highest smoking prevalence.

Finally, the $\mathrm{X}$ Generation entered adolescence during the fourth stage, when smoking rates declined for both sexes, with exception of less-educated women, who entered the diffusion process later than their more highly educated counterparts. Hence, socio-economic differences in smoking have increased especially for women in this generation, and smoking has become a problem among lower socioeconomic groups, even though the reduction in smoking prevalence is declining farther and faster for less-educated men in the X Generation.

\subsection{The North- South Gradient in the Diffusion Process}

Italy has cultural and institutional features that are unusual for a European country. Southern Italy is Europe's principal empirical case of failed modernization and is often used by researchers as a case study of underdevelopment (Chubb, 1982; Micali, 2009; Carrieri et al., 2014). The productivity rates diverged the most in the post-World War II era, the same period in which smoking started to spread, as per 
capita consumption (for Italians 15 and older) of legally sold tobacco increased from about $0.800 \mathrm{~kg}$ per person per year in 1950 to about $2.3 \mathrm{~kg}$ in the $1980 \mathrm{~s}$ and then declined (ISTAT, 1952; 1982).

The economic and social dualism between the more economically developed northern regions and the less developed southern ones may have interacted with the progression of smoking epidemic. Until the end of the 1980s, per capita consumption of tobacco was higher in the northern regions, but at the beginning of the 1990s a reversal from the North to the South occurred and smoking became progressively more a habit of the southern regions. ${ }^{6}$

To determine whether there was a North-South gradient in smoking diffusion, we re-ran the model, dividing the two samples of males and females into subsamples using geographic dummies for the macro-regions.

Figures $3 \mathrm{a}$ and $3 \mathrm{~b}$ show the north-south patterns of age profiles in the smoking habit across generations. We observe a north-south gradient among men, with higher smoking prevalence in the southern part of Italy, but no such geographical pattern for women, as women in the southern region are less likely to smoke than those in the northern region. Traditional cultural norms against women's smoking and the lower social and economic status of southern women are the most likely causes of these differences in women's smoking behavior.

Table 3 shows the estimation results for males. Among men, southern Italy appears to lag one generation behind northern Italy: while the more healthful trend starts with the Baby Boomer 2 Generation in the northern regions, the decline in smoking prevalence starts with the X Generation in the southern regions; in general, the reduction in the prevalence across generations is higher in the North than it is in the South.

Women of both education levels who live in the southern regions have the most favorable smoking profile (Table 4). The generational gap concerns the less-educated women only: in the northern regions, smoking prevalence of the youngest generations of less-educated women is higher than that of the Silent Generation but lower than those of the Baby Boomer 1 and 2 Generations. Therefore, in the northern regions, the

\footnotetext{
${ }^{6}$ In northern regions, per capita consumption (for Italians age 15 and older) of legally sold tobacco was about $0.700 \mathrm{~kg}$ in $1951,1.4 \mathrm{~kg}$ in $1971,2.3 \mathrm{~kg}$ in 1981, and $0.200 \mathrm{~kg}$ in 1991. In the southern regions, consumption was about $0.500 \mathrm{~kg}$ in 1951, $1.2 \mathrm{~kg}$ in 1971, $2.2 \mathrm{~kg}$ in 1981, and $1.7 \mathrm{~kg}$ in 1991 (ISTAT, $1952 ; 1972 ; 1982 ; 1992)$.
} 
decline in the unhealthful trend of smoking started with the $\mathrm{X}$ Generation. In contrast, in the southern regions, women in the younger generations smoke more often than their predecessors and are more likely to smoke than are women in the Silent or the Baby Boomer 1 Generations, and even though smoking prevalence in Generation $\mathrm{X}$ is slightly declining compared to that of the Baby Boomer 2 Generation.

\section{Conclusions}

The picture the 2016 ISTAT report painted of Italy was one of a country with an aging population. As in other industrialized countries, the social structure in Italy has changed radically. Longevity will be an issue for the whole century and will grow in intensity over the next few years, when it will be the Baby Boomer Generation that starts aging.

Today, the Baby Boomers are the largest generation in Italy and elsewhere, and one of the main worries is whether the National Health Service will be able to meet the growing needs of this generation as it ages. Our results show that the Baby Boomer Generation is an "unhealthy" generation that smokes more than it did in the past and more than the younger generation does. In particular, among men, the least healthy were born between 1946 and 1955 (Baby Boomers 1), are less-educated, and live in southern Italy. Among women, who lagged one generation in the smoking diffusion process, the least healthy were born between 1956 and 1965 (Baby Boomers 2), are less-educated, and live in northern Italy. According to our results, the proportion of men and women in Italy who smoke is decreasing with subsequent generations. The youngest generation, born between 1966 and 1980 (the X Generation), presents the most favorable smoking profile, with the exception of lesseducated women who live in southern Italy and who, because of socio-cultural factors, came later to the smoking epidemic than did their northern counterparts. According to Rogers' TDI, smoking prevalence is expected to decline further, particularly among less-educated women, while the future burden of smoking-related diseases is expected to increase, particularly among the Baby Boomers, confirming the reasons for concern. 


\section{References}

Assaf, S., Campostrini, S., Di Novi, C., Fang, X., \& Gotway Crawford, C. (2017). Analyzing Disparities Trends for Health Care Insurance Coverage Among NonElderly Adults in the US: Evidence from the Behavioural Risk Factor Surveillance System, 1993-2009. The European Journal of Health Economics, 18, 387-398.

Banks, J., Blundell, R., \& Tanner, S. (1998). Is There a Retirement-Savings Puzzle? The American Economic Review, 88, 769-788.

Bell, A., \& Jones, K. (2013). The impossibility of separating age, period and cohort effects. Social Science \& Medicine, 93, 163-165.

Carrieri, V., Di Novi, C., Jacobs, R., \& Robone, S. (2014). Insecure, sick and unhappy? Well-being consequences of temporary employment contracts. In: Polachek, S.W., \& Tatsiramos, K. (Eds.) Factors Affecting Worker Well Being: The Impact of Change in the Labor Economics, 40, 157-193. Emerald Group Publishing Limited.

Clark, A., Knabe, A., \& Ratzel, S. (2010). Boon or Bane? Others' Unemployment, Wellbeing and Job Insecurity. Labour Economics, 17, 52-61.

Chang, T., Chu, H.P., Deale, F.W., \& Gupta, R. (2016). The causal relationship between happiness and smoking: a bootstrap panel causality test. Journal of Happiness Studies, 17, 1327-1336. Chubb, J. (1982). Patronage, power, and poverty in southern Italy. A tale of two cities. Cambridge: Cambridge University Press.

Deaton, A. (1985). Panel Data from Time Series of Cross-Sections. Journal of Econometrics, 30, 109-126.

Di Novi, C., Migheli, M., \& Jacobs, R. (2017). Smoking Inequality across Genders and Social Classes. Evidence from Longitudinal Italian Data. mimeo.

Glenn, N.D. (2005). Cohort analysis. Beverly Hills: Sage.

Hunt, K., Hannah, M.K. \& West, P. (2004). Contextualizing Smoking: Masculinity, Femininity and Class Differences in Smoking in Men and Women from Three Generations in the West of Scotland. Health Education Research, 19, 239 - 249.

Ipsen, C. (2016). Fumo: Italy's Love Affair With the Cigarette. Stanford: Stanford University Press.

ISTAT (2016). Rapporto annuale 2016. La situazione del Paese. Roma (IT): Istat Press. Kaiser, M., Reutter, M., Sousa-Poza, A., \& Strohmaier, K. (2017). Smoking and the Business Cycle: Evidence from Germany. IZA Discussion Paper, 10953. 
La Vecchia, C., Decarli, A., \& Pagano, R. (1986). Prevalence of cigarette smoking among subsequent cohorts of males and females in Italy. Preventive Medicine, 15, 606-13.

Lopez, A. D., Collishaw, N. E., \& Piha, T. (1994). A descriptive model of the cigarette epidemic in developed countries. Tobacco Control, 3, 242-247.

Mackenbach, J. (2006). Health inequalities: Europe in profile. Rotterdam: Erasmus MC University Medical Center.

Micali, S. J. (2009). Italy: The Case for Division, Pell Scholars and Senior Theses. Paper 50. Retrieved from http://escholar.salve.edu/pell_theses/50.

Pampel, F. C. (2005). Diffusion, cohort change, and social patterns of smoking. Social Science Resources, 34, 117-139.

Propper, C., Rees, H., \& Green, K. (2001). The Demand for Private Medical Insurance in the UK: A Cohort Analysis. The Economic Journal, 111, C180- C200.

Rogers, E. M. (2003). Diffusion of innovations (5 ed.). New York: Free press.

Ruhm, C. J. (2005). Healthy living in hard times. Journal of Health Economics, 24, 341-363.

Tinkler, P. (2006). Smoke signals: women smoking and visual culture in Britain. Oxford: Berg.

Veday, T. F. (2014). Tracing the cigarette epidemic: An age-period-cohort study of education, gender and smoking using a pseudo-panel approach, Social Science Research, 48, 35-47.

Verbeek, M. (2008). Pseudo-panels and repeated cross-sections. In: Matyas, L., \& Sevestre, P. (Eds.), The Econometrics of Panel Data. Springer-Verlag, Berlin, pp. $369-383$.

van Kippersluis, H., van Ourti, T., O’Donnell, O., \& van Doorslaer, E. (2009). Health and income across the life cycle and generations in Europe, Journal of Health Economics, 28, 818-83.

Samet, J. M., \& Yoon, SY. (2010). Gender and Tobacco: Challenges for the $21^{\text {st }}$ Century. Geneva: World Health Organization. 
Figure 1: Smoking Prevalence by Age across Generations (Female vs Male)

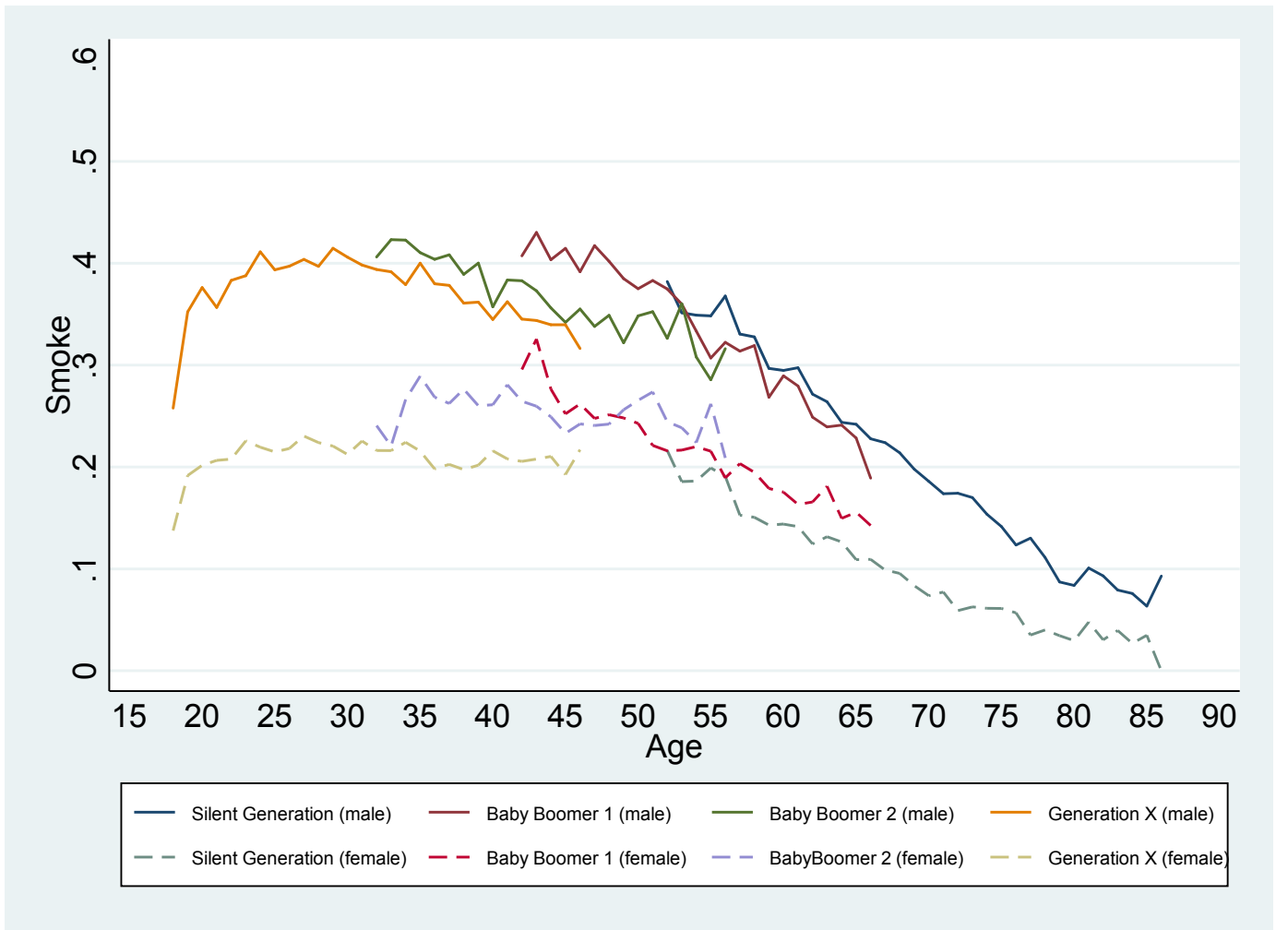

Figure 2a: Smoking Prevalence by Age and Educational Level across Generations (Female vs Male) - Voluntary Education

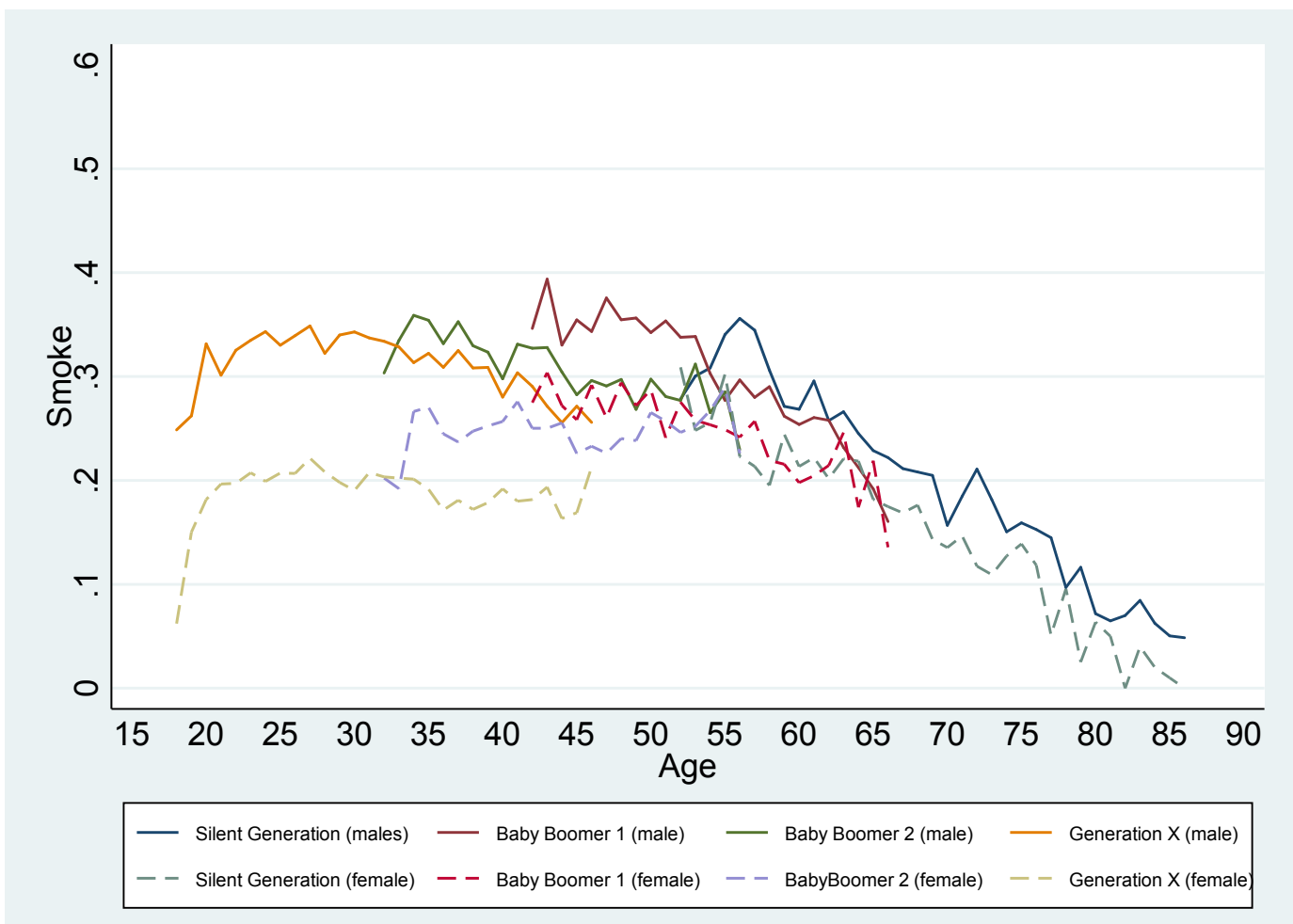


Figure 2b: Smoking Prevalence by Age and Educational Level across Generations (Female vs Male) - Compulsory Education

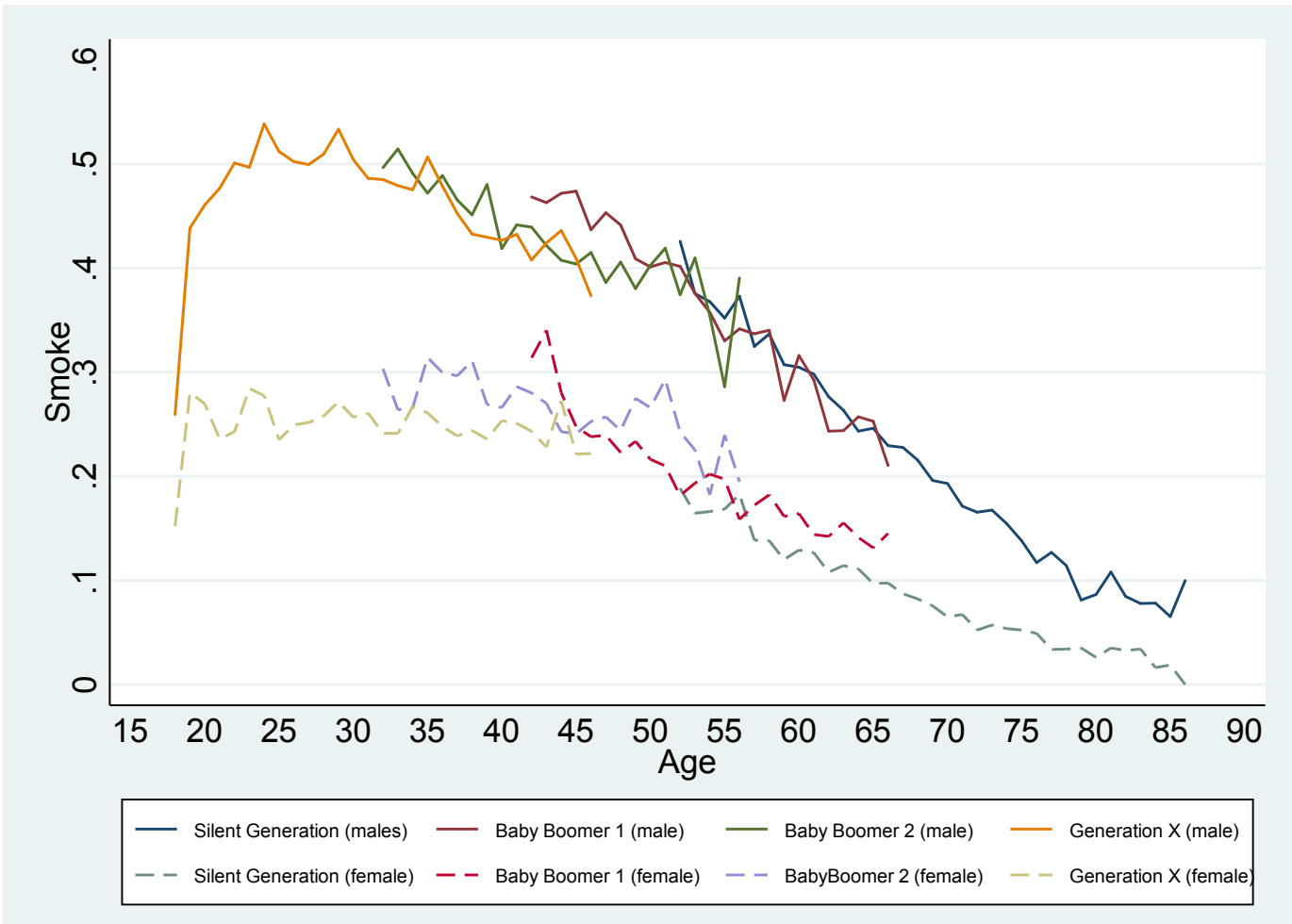

Table 1a: Descriptive statistics for Italian males (18 years and over): 1997-2012

\begin{tabular}{|c|c|c|c|c|c|c|c|c|}
\hline & \multicolumn{4}{|c|}{ Percentage of smokers } & \multicolumn{4}{|c|}{ Population distribution } \\
\hline & $\begin{array}{l}\text { Silent } \\
\text { Generation }\end{array}$ & $\begin{array}{l}\text { Baby } \\
\text { Boomer } 1\end{array}$ & $\begin{array}{l}\text { Baby } \\
\text { Boomer } \\
2\end{array}$ & $\begin{array}{l}\text { Generation } \\
\mathrm{X}\end{array}$ & $\begin{array}{l}\text { Silent } \\
\text { Generation }\end{array}$ & $\begin{array}{l}\text { Baby } \\
\text { Boomer } 1\end{array}$ & $\begin{array}{l}\text { Baby } \\
\text { Boomer } \\
2\end{array}$ & $\begin{array}{l}\text { Generation } \\
\text { X }\end{array}$ \\
\hline Age & & & & & & & & \\
\hline $18-34$ & & & 0.4202 & 0.3931 & & & 0.0517 & 0.6770 \\
\hline $35-49$ & & 0.4033 & 0.3686 & 0.3653 & & 0.2728 & 0.7935 & 0.3230 \\
\hline $50-64$ & 0.2975 & 0.3211 & 0.3369 & & 0.3733 & 0.7112 & 0.1548 & \\
\hline $65+$ & 0.1769 & 0.2146 & & & 0.6267 & 0.0160 & & \\
\hline $\begin{array}{l}\text { Education } \\
\text { level }\end{array}$ & & & & & & & & \\
\hline Low & 0.2158 & 0.3600 & 0.4241 & 0.4724 & 0.7899 & 0.5762 & 0.4958 & 0.4065 \\
\hline High & 0.2268 & 0.3101 & 0.3092 & 0.3212 & 0.2101 & 0.4238 & 0.5042 & 0.5935 \\
\hline $\begin{array}{l}\text { Macro } \\
\text { Regions }\end{array}$ & & & & & & & & \\
\hline Northern & 0.2036 & 0.3071 & 0.3280 & 0.3574 & 0.4437 & 0.4226 & 0.4270 & 0.4157 \\
\hline Southern & 0.2369 & 0.3753 & 0.4134 & 0.4093 & 0.3591 & 0.3910 & 0.3932 & 0.4081 \\
\hline
\end{tabular}


Table 1b: Descriptive statistics for Italian women (18 years and over): 1997-2012

\begin{tabular}{|c|c|c|c|c|c|c|c|c|}
\hline & \multicolumn{4}{|c|}{ Percentage of smokers } & \multicolumn{4}{|c|}{ Population distribution } \\
\hline & $\begin{array}{l}\text { Silent } \\
\text { Generation }\end{array}$ & $\begin{array}{l}\text { Baby } \\
\text { Boomer } \\
1\end{array}$ & $\begin{array}{l}\text { Baby } \\
\text { Boomer } \\
2\end{array}$ & $\begin{array}{l}\text { Generation } \\
\mathrm{X}\end{array}$ & $\begin{array}{l}\text { Silent } \\
\text { Generation }\end{array}$ & $\begin{array}{l}\text { Baby } \\
\text { Boomer } 1\end{array}$ & $\begin{array}{l}\text { Baby } \\
\text { Boomer } 2\end{array}$ & $\begin{array}{l}\text { Generation } \\
\mathrm{X}\end{array}$ \\
\hline Age & & & & & & & & \\
\hline $18-34$ & & & 0.2470 & 0.2178 & & & 0.0525 & 0.6677 \\
\hline $35-49$ & & 0.2597 & 0.2576 & 0.2057 & & 0.2726 & 0.7905 & 0.3323 \\
\hline $50-64$ & 0.1471 & 0.2010 & 0.2529 & & 0.34206 & 0.7117 & 0.1569 & \\
\hline $65+$ & 0.0724 & 0.1516 & & & 0.65794 & 0.0157 & & \\
\hline $\begin{array}{l}\text { Education } \\
\text { level }\end{array}$ & & & & & & & & \\
\hline Low & 0.0823 & 0.1927 & 0.2660 & 0.2500 & 0.8761 & 0.6488 & 0.4748 & 0.3353 \\
\hline High & 0.1748 & 0.2511 & 0.2477 & 0.1943 & 0.1239 & 0.3512 & 0.5258 & 0.6650 \\
\hline $\begin{array}{l}\text { Macro } \\
\text { Regions }\end{array}$ & & & & & & & & \\
\hline Northern & 0.1105 & 0.2217 & 0.2564 & 0.2180 & 0.4444 & 0.4254 & 0.4148 & 0.4099 \\
\hline Southern & 0.0584 & 0.1786 & 0.2430 & 0.1901 & 0.3603 & 0.3889 & 0.4015 & 0.4137 \\
\hline
\end{tabular}

Table 2 - Male - Theory of diffusion of innovations (TDI) taking into account the separate effects of age and birth cohort (AC)

Age

Generations (ref. Silent

Generation)

Baby Boomer 1

Baby Boomer 2

Generation X

Voluntary Education

Compulsory Education

Constant

Regional Fixed Effects

Observations

Adj R-squared

\begin{tabular}{|c|c|c|c|c|c|}
\hline Coef. & $\begin{array}{l}\text { Std. } \\
\text { Err. }\end{array}$ & $\mathrm{P}>\mathrm{t}$ & Coef. & $\begin{array}{l}\text { Std. } \\
\text { Err. }\end{array}$ & $\mathrm{P}>\mathrm{t}$ \\
\hline-0.0043 & 0.0003 & 0.000 & -0.0089 & 0.0003 & 0.000 \\
\hline 0.0263 & 0.0068 & 0.000 & 0.0169 & 0.0062 & 0.007 \\
\hline-0.0182 & 0.0089 & 0.052 & -0.0133 & 0.0090 & 0.143 \\
\hline-0.0596 & 0.0122 & 0.000 & -0.0689 & 0.0124 & 0.000 \\
\hline 0.5056 & 0.0225 & 0.000 & 0.8179 & 0.0228 & 0.000 \\
\hline \multicolumn{3}{|c|}{$Y E S$} & \multicolumn{3}{|c|}{$Y E S$} \\
\hline 1093 & & & 1137 & & \\
\hline 0.4301 & & & 0.8451 & & \\
\hline
\end{tabular}


Table 3 - Female - Theory of diffusion of innovations (TDI) taking into account the separate effects of age and birth cohort (AC)

Age

Voluntary Education

Compulsory Education

Generations (ref. Silent

Generation)

Baby Boomer 1

Baby Boomer 2

Generation X

Constant

Regional Fixed Effects

Observations

Adj R-squared

\begin{tabular}{|lll|lll|}
\hline Coef. & $\begin{array}{l}\text { Std. } \\
\text { Err. }\end{array}$ & P $>\mathrm{t}$ & Coef. & $\begin{array}{l}\text { Std. } \\
\text { Err. }\end{array}$ & $\mathrm{P}>\mathrm{t}$ \\
\hline-0.0022 & 0.0000 & 0.000 & -0.0032 & 0.0003 & 0.000 \\
& & & & & \\
& & & & & \\
0.0507 & 0.0069 & 0.000 & 0.0658 & 0.0049 & 0.000 \\
0.0233 & 0.0085 & 0.006 & 0.1109 & 0.0072 & 0.000 \\
-0.0553 & 0.0113 & 0.000 & 0.0621 & 0.0099 & 0.000 \\
& & & & & \\
0.3131 & 0.0203 & 0.000 & 0.3247 & 0.0181 & 0.000 \\
& & & & & \\
\hline 1031 & & & 1037 & & \\
0.4264 & & & 0.8280 & & \\
\hline
\end{tabular}

Figure 3a: Smoking Prevalence by Age across Generations (Male): North-South Gradient

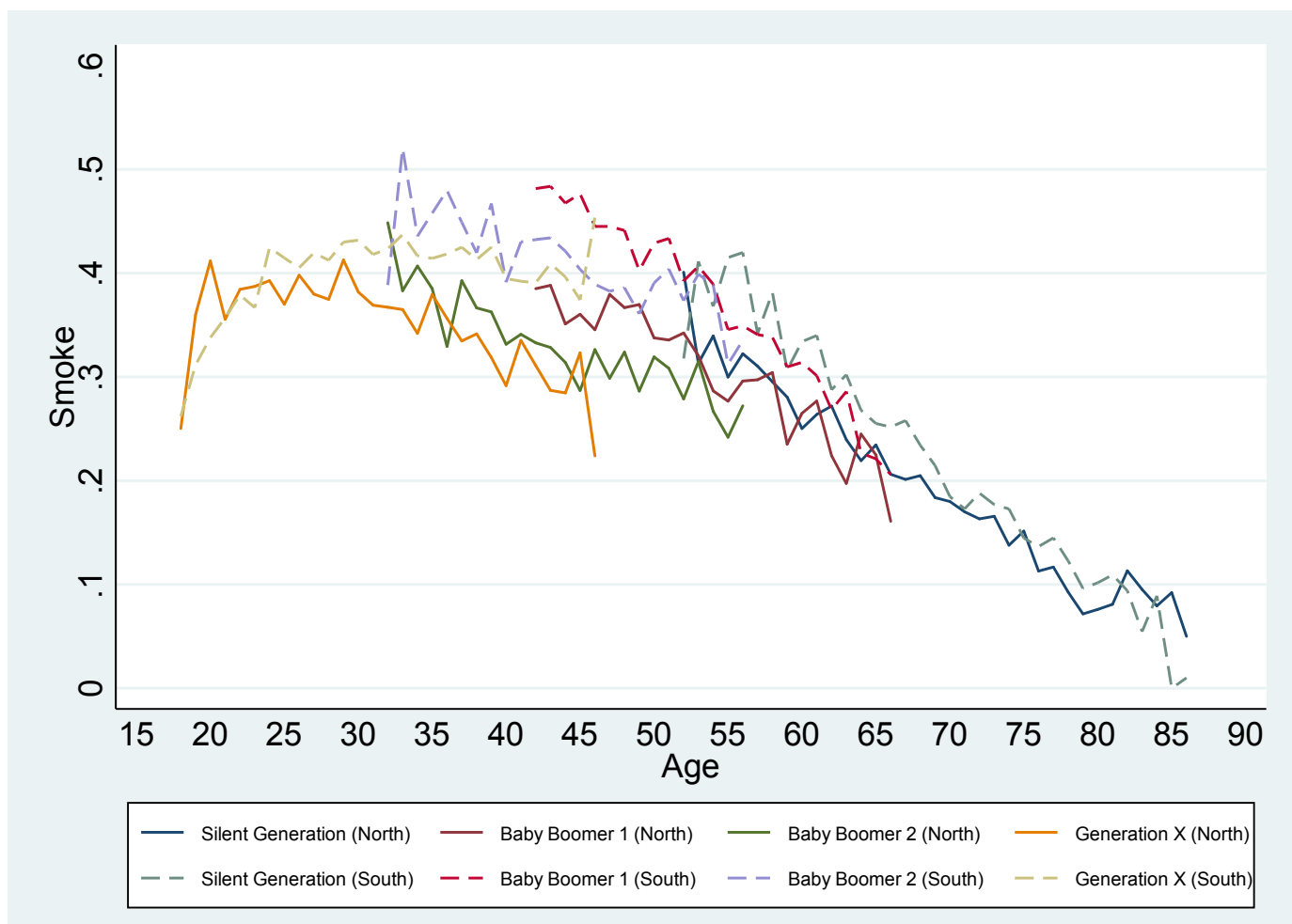


Figure 3b: Smoking Prevalence by Age across Generations (Female): North-South Gradient

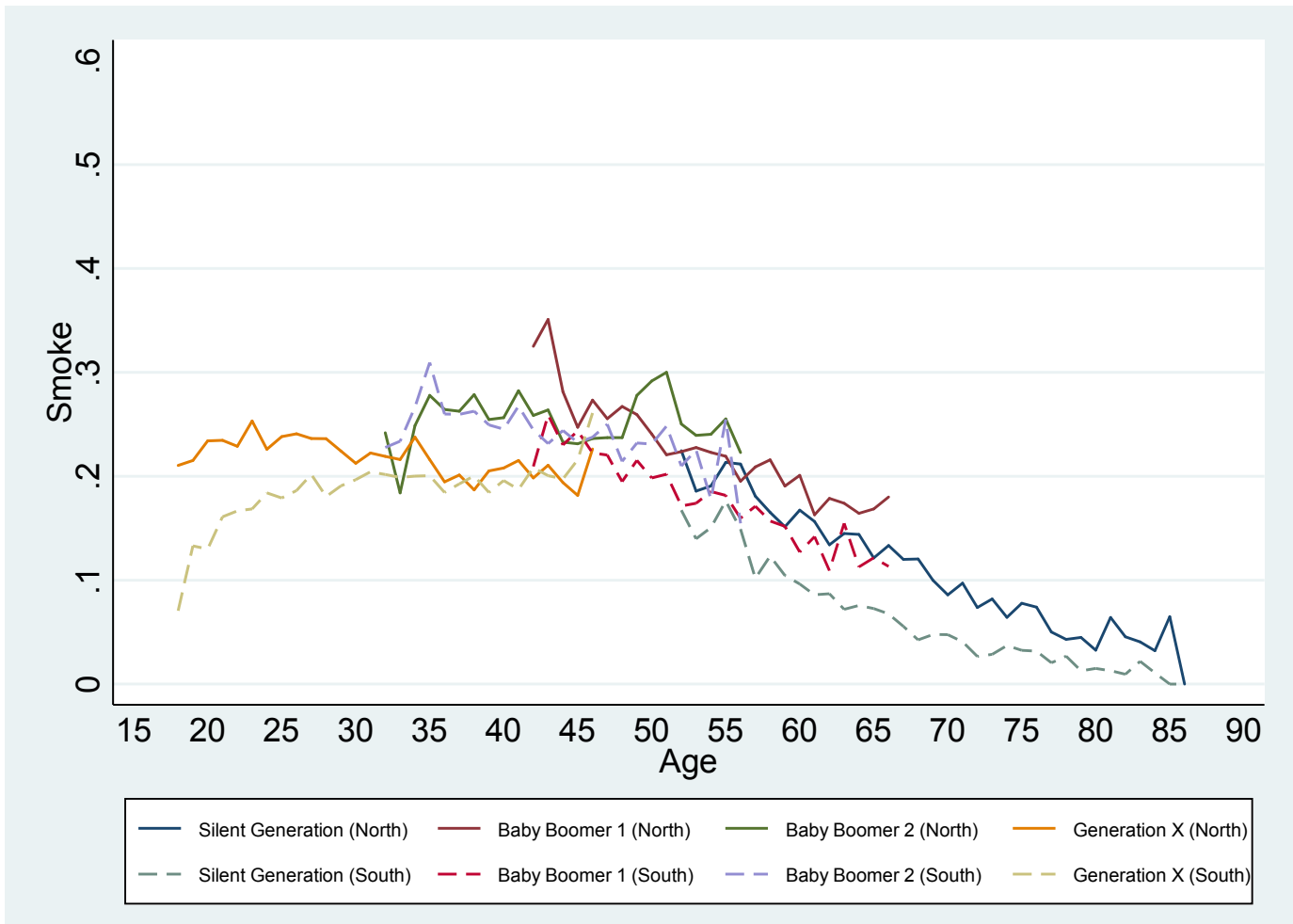


Table 4 - Male - Theory of diffusion of innovations (TDI) taking into account the separate effects of age and birth cohort (AC): North-South Gradient

Age

Generations (ref. Silent Generation)

Baby Boomer 1

Baby Boomer 2

Generation X

North

Voluntary Education

South

Voluntary Education

\begin{tabular}{|lll|lll|}
\hline Coef. & $\begin{array}{l}\text { Std. } \\
\text { Err. }\end{array}$ & $\mathrm{P}>\mathrm{t}$ & Coef. & $\begin{array}{l}\text { Std. } \\
\text { Err. }\end{array}$ & $\mathrm{P}>\mathrm{t}$ \\
\hline & & & & & \\
-0.0046 & 0.0004 & 0.000 & -0.0040 & 0.0005 & 0.000 \\
& & & & & \\
& & & & & \\
0.0158 & 0.0094 & 0.095 & 0.0366 & 0.0127 & 0.004 \\
-0.0349 & 0.0124 & 0.005 & 0.0054 & 0.0163 & 0.737 \\
-0.0694 & 0.0169 & 0.000 & -0.0493 & 0.0223 & 0.027 \\
& & & & & \\
0.5323 & 0.0308 & 0.000 & 0.4647 & 0.0399 & 0.000 \\
& & & & & \\
& $Y E S$ & & & $Y E S$ & \\
\hline 420 & & & 438 & & \\
0.4450 & & & 0.2887 & & \\
\hline
\end{tabular}

Age

Generations (ref. Silent

Generation)

Baby Boomer 1

Baby Boomer 2

Generation X

Constant

Regional Fixed Effects

Observations

Adj R-squared

North

South

Compulsory Education

Compulsory Education

\begin{tabular}{|lll|lll|}
\hline Coef. & $\begin{array}{l}\text { Std. } \\
\text { Err. }\end{array}$ & P >t & Coef. & $\begin{array}{l}\text { Std. } \\
\text { Err. }\end{array}$ & P >t \\
\hline-0.0089 & 0.0004 & 0.000 & -0.0085 & 0.0004 & 0.000 \\
& & & & & \\
& & & & & \\
-0.0011 & 0.0092 & 0.908 & 0.0408 & 0.0103 & 0.000 \\
-0.0428 & 0.0135 & 0.002 & 0.0230 & 0.0148 & 0.121 \\
-0.0787 & 0.0184 & 0.000 & -0.0538 & 0.0204 & 0.009 \\
0.832 & 0.0337 & 0.000 & 0.7660 & 0.0368 & 0.000 \\
& & & & & \\
& & & & & \\
\hline 420 & & & 480 & \\
0.8388 & & & 0.8265 & & \\
\hline
\end{tabular}


Table 5 - Female - Theory of diffusion of innovations (TDI) taking into account the separate effects of age and birth cohort (AC): North-South Gradient

Age

North

Voluntary Education

South

Voluntary Education

Generations (ref. Silent

Generation)

Baby Boomer 1

Baby Boomer 2

Generation X

Constant

Regional Fixed Effects

Observations

Adj R-squared

\begin{tabular}{|lll|lll|}
\hline Coef. & $\begin{array}{l}\text { Std. } \\
\text { Err. }\end{array}$ & P >t & Coef. & $\begin{array}{l}\text { Std. } \\
\text { Err. }\end{array}$ & P >t \\
\hline & & & & & \\
-0.0020 & 0.0004 & 0.000 & -0.0014 & 0.0005 & 0.004 \\
& & & & & \\
& & & & & \\
0.0498 & 0.0092 & 0.000 & 0.0661 & 0.0125 & 0.000 \\
0.0159 & 0.0116 & 0.171 & 0.0554 & 0.0149 & 0.000 \\
-0.0446 & 0.0154 & 0.004 & -0.0453 & 0.0195 & 0.021 \\
& & & & & \\
0.3052 & 0.0276 & 0.000 & 0.2502 & 0.0339 & 0.000 \\
& & & & & \\
& & & & & \\
\hline 406 & & & 405 & \\
0.3660 & & & 0.4732 & & \\
\hline
\end{tabular}

Age

Generations (ref. Silent

Generation)

Baby Boomer 1

Baby Boomer 2

Generation X

Constant

Regional Fixed Effects

Observations

Adj R-squared

North

South

Compulsory Education

Compulsory Education

\begin{tabular}{|lll|lll|}
\hline Coef. & $\begin{array}{l}\text { Std. } \\
\text { Err. }\end{array}$ & $\mathrm{P}>\mathrm{t}$ & Coef. & $\begin{array}{l}\text { Std. } \\
\text { Err. }\end{array}$ & $\mathrm{P}>\mathrm{t}$ \\
\hline & & & & & \\
-0.0040 & 0.0004 & 0.000 & -0.0017 & 0.0004 & 0.000 \\
& & & & & \\
& & & & & \\
0.0537 & 0.0075 & 0.000 & 0.0695 & 0.0077 & 0.000 \\
0.0895 & 0.0113 & 0.000 & 0.1388 & 0.0111 & 0.000 \\
0.0333 & 0.0153 & 0.030 & 0.1017 & 0.0152 & 0.000 \\
& & & & & \\
0.3846 & 0.0278 & 0.000 & 0.2026 & 0.0275 & 0.000 \\
& & & & & \\
& $Y E S$ & & & $Y E S$ & \\
\hline 420 & & & 480 & & \\
0.8308 & & & 0.8110 & & \\
\hline
\end{tabular}




\section{APPENDIX}

Table A.1: Stop-smoking services per 100.000 inhabitants

\begin{tabular}{lcc}
\hline Period & $\begin{array}{c}\text { Northern } \\
\text { Regions }\end{array}$ & $\begin{array}{c}\text { Southern } \\
\text { Regions }\end{array}$ \\
\hline \hline 1997 & 0.1461 & 0.0435 \\
1998 & 0.1695 & 0.0533 \\
1999 & 0.2204 & 0.0582 \\
2000 & 0.3022 & 0.0826 \\
2001 & 0.3915 & 0.1705 \\
2002 & 0.5569 & 0.3507 \\
2003 & 0.6707 & 0.4076 \\
2004 & 0.6620 & 0.4347 \\
2005 & 0.6361 & 0.3999 \\
2006 & 0.6915 & 0.3902 \\
2007 & 0.7451 & 0.3848 \\
2008 & 0.7118 & 0.4174 \\
2009 & 0.7312 & 0.3977 \\
2010 & 0.7552 & 0.4690 \\
2011 & 0.7351 & 0.3998 \\
\hline
\end{tabular}

Source: Stop-smoking services data available at http:// www.iss.it/fumo/; inhabitants data available at http://www3.istat.it/sanita/Health/

Table A.2: Size Distribution of cells (1997-2012)

\begin{tabular}{|l|l|l|l|}
\hline Sample & Mean & Min & Max \\
\hline Male & 122 & 31 & 620 \\
\hline Female & 133 & 31 & 768 \\
\hline
\end{tabular}

\section{Robustness Check}

In order to test the robustness of our results, we also re-run the model by assuming that period effects on the smoking prevalence could derive from a business cycle effect operating through economic conditions. Indeed, Clark et al. (2010) show that changes in aggregate economic conditions affect subjective well-being, which may also influence the propensity towards smoking (Ruhm, 2005; Chang et al., 2016; Kaiser et al., 2017). 
We include in the regression model the GDP growth rate. Even though the inclusion of period effects, which derive from business cycle fluctuations, lowered the precision of the estimates of the age and cohort effects, the patterns of the age and cohort profiles remain similar.

Table A.3a - Male - Theory of diffusion of innovations (TDI) taking into account the separate effects of age and birth cohort (AC) and GDP growth rate

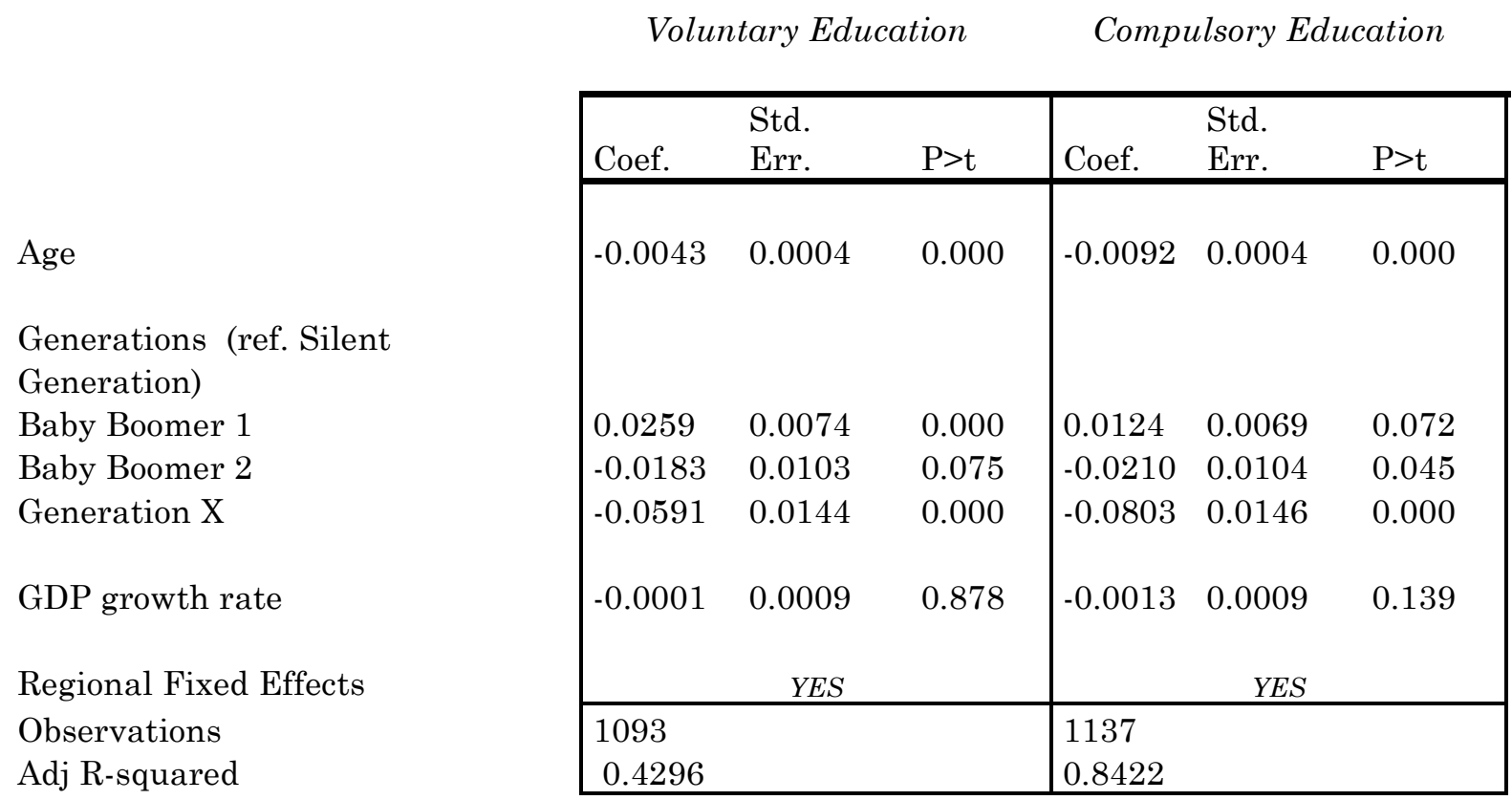

Table A.4b - Female - Theory of diffusion of innovations (TDI) taking into account the separate effects of age and birth cohort (AC) and GDP growth rate

Age

Voluntary Education Compulsory Education

Generations (ref. Silent

Generation)

Baby Boomer 1

Baby Boomer 2

Generation X

GDP growth rate

Regional Fixed Effects

Observations

Adj R-squared

\begin{tabular}{|lll|lll|}
\hline Coef. & $\begin{array}{l}\text { Std. } \\
\text { Err. }\end{array}$ & P $>\mathrm{t}$ & Coef. & $\begin{array}{l}\text { Std. } \\
\text { Err. }\end{array}$ & $\mathrm{P}>\mathrm{t}$ \\
\hline-0.0021 & 0.0003 & 0.000 & -0.0032 & 0.0003 & 0.000 \\
& & & & & \\
& & & & & \\
0.0515 & 0.0073 & 0.000 & 0.0658 & 0.0054 & 0.000 \\
0.0248 & 0.0096 & 0.010 & 0.1108 & 0.0083 & 0.000 \\
-0.0531 & 0.0131 & 0.000 & 0.0621 & 0.0115 & 0.000 \\
& & & & & \\
0.0003 & 0.0008 & 0.742 & -0.0000 & 0.0007 & 0.986 \\
& & & & & \\
\hline 1031 & & & 1137 & & \\
0.4259 & & & 0.8279 & & \\
\hline
\end{tabular}

